\title{
IMAGENS PARA \\ ALÉM DA LINGUAGEM?: \\ O ANACRONISMO DA HIPÓTESE \\ FOUCAULTIANA DE UMA “RUÍNA \\ DO SIMBOLISMO GÓTICO” EM HISTÓRIA DA LOUCURA
}

\author{
¿IMÁGENES MÁS ALLÁ DEL LENGUAJE?: EL ANACRONISMO DE LA HIPÓTESIS \\ FOUCAULDIANA DE UNA "RUÍNA DEL SIMBOLISMO GÓTICO" EN HISTORIA DE LA \\ LOCURA
}

IMAGES BEYOND LANGUAGE?: THE ANACHRONISM IN FOUCAULT'S HIPOTESIS OF THE "DECAY OF GOTHIC SYMBOLISM" IN HISTORY OF MADNESS

Gabriel Pinezi*

UNESP-Araraquara

Renan Pavini** PUC-PR

\footnotetext{
RESUMO: História da Loucura é um texto marcado pela crítica à tradição dialética que Nietzsche havia esboçado em seu Nascimento da Tragédia. Isto fica evidente quando Foucault diferencia dois tipos de "experiências" da loucura no limiar entre medievo e renascimento: uma experiência trágica da loucura, imperante nas artes plásticas de Bosch e Bruegel, em oposição a uma experiência crítica, que se expressa majoritariamente em textos literários moralistas e cômicos como de Brant e Erasmo. Com base nessa distinção, Foucault propõe que a diferença entre a experiência trágica e crítica da loucura se dá quando as imagens de Bosch revelam

* Doutor e mestre em Letras pela UEL. Foi pós-doutorando do PPG em Estudos Literários da UNESP-Araraquara (Bolsista PNPD) entre 2018 e 2019 . Atualmente é professor colaborador do departamento de Letras da UNICENTRO-Guarapuava e da Especializaçãoem Literaturada UNESPAR-Campo Mourão.E-mail:gabrielpinezi@gmail.com. 
os limites da linguagem verbal, acontecimento histórico que chamou de "ruína do simbolismo gótico". O objetivo deste artigo é ressaltar a anacronia desta interpretação histórica de Foucault, apontando para como a crítica de Nietzsche à tradição dialética de Platão e Hegel contribuiu para a formulação de uma hipótese sem rigor historiográfico.

PALAVRAS-CHAVE: Experiência trágica da loucura. Experiência crítica da loucura. Simbolismo. Linguagem. Logos.

RESUMEN: Historia de la Locura es un texto marcado por la crítica a la tradición dialéctica que Nietzsche había esbozado en su Nacimiento de la Tragedia. Esto queda evidente cuando Foucault diferencia dos tipos de "experiencias" de la locura en el umbral entre medievo y renacimiento: una experiencia trágica de la locura, imperante en las artes plásticas de Bosch y Bruegel, en oposición a una experiencia crítica, que se expresa mayoritariamente en textos literarios moralistas y cómicos como de Brant y Erasmo. Con base en esta distinción, Foucault propone que la diferencia entre la experiencia trágica y crítica de la locura se da cuando las imágenes de Bosch revelan los límites del lenguaje verbal, acontecimiento histórico que lo llamó de "ruina del simbolismo gótico". El objetivo de este artículo es resaltar la anacronía de esta interpretación histórica de Foucault, apuntando hacia cómo la crítica de Nietzsche a la tradición dialéctica de Platón y Hegel contribuyó a la formulación de una hipótesis sin rigor historiográfico.

PALABRAS-CLAVE: Experiencia trágica de la locura. Experiencia crítica de la locura. Simbolismo. Lenguaje. Logos.

ABSTRACT: History of Madness is a text marked by the same critique of the dialectical tradition defended by Nietzsche in The Birth of Tragedy. This becomes clear when Foucault differentiates two types of "experiences" of madness in the frontier between Medievalism and Renaissance: a tragic experience of madness, which reigns on the pictorial arts by Bosch and Bruegel, opposed to a critical experience, majorly expressed in comical and moral literary texts by Brant and Erasmus. Based on this distinction, Foucault asserts that the difference between the tragic and the critical experiences of madness occurs when Bosch reveals the limits of verbal language, historical fact acknowledged by Foucault as "the decay of Gothic symbolism". The aim of this essay is to reveal the anachronism of Foucault's historical interpretation, stressing how Nietzsche's critique of the dialectical tradition of Plato and Hegel contributed to the formulation of a hypothesis without historiographic rigor.

KEYWORDS: Tragical experience of madness. Critical experience of madness. Symbolism. Language. Logos.

\section{INTRODUÇÃO: EXPERIÊNCIA TRÁGICA E CONSCIÊNCIA CRÍTICA DA LOUCURA}

Em sua tese de doutorado, Folie et derasión. Histoire de la folie à l'âge classique, Foucault confrontou, logo em seu prefácio ${ }^{1}$, as dialéticas da história com as estruturas imóveis do trágico. Sob este escopo, afirmou que, para refazer uma história da loucura sem recair nos discursos positivos que modernamente a cercam, era preciso fugir das verdades terminais impostas pelos discursos psicopatológicos, lançando um novo olhar ao outro giro [autre tour] da loucura para, assim, reescrever a história em sua verticalidade. Tal verticalidade só é possível, para Foucault, quando se colocam em evidência os limites da história Ocidental, em detrimento da identidade imposta por essa mesma cultura. Ou, em outras palavras, a identidade de uma cultura só pode ser historicamente formada na recusa daquilo que ela exclui. Declaradamente, Foucault começa a preparar o terreno para sua arqueologia do silêncio através da filosofia de Nietzsche: "[...] o estudo que se lerá só seria o primeiro, e o mais fácil sem dúvida, dessa longa investigação na qual, sob o sol da grande pesquisa nietzschiana, quero confrontar as dialéticas da história com as estruturas imóveis do trágico" (FOUCAULT, 1994, p. 1962)².

Roberto Machado (2005, p. 25), ao comentar História da loucura, escreve que este é um texto que "[...] apresenta uma homologia estrutural surpreendente" com O nascimento da tragédia de Nietzsche, principalmente por causa da "[...] tese da existência de uma experiência trágica da loucura”. Nietzsche proclama, com Eurípedes e o socratismo, a morte da tragédia; já Foucault observa uma sobreposição da consciência crítica sobre a experiência trágica na passagem do século XVI ao XVII, resultando num processo de

\footnotetext{
${ }^{1}$ Prefácio presente na primeira edição do texto, de 1961, publicado pela editora Plon. Posteriormente, em sua segunda edição, pela editora Gallimard, Foucault suprime Folie et dérasion do título e substitui o primeiro prefácio por um mais conciso, que traz a problemática da autoria, afastando-se assim do ar romântico do primeiro.

${ }^{2}$ Tradução nossa. O mesmo se aplica a outras citações cujo original se encontra em língua estrangeira.
} 
racionalização da loucura que alcançará plena expressão com a racionalidade moderna. E, do mesmo modo com que Nietzsche compreende a história Ocidental como a recusa da tragédia e acredita que seu renascimento pode ser observado na filosofia de Schopenhauer e na música de Wagner, Foucault compreende a história clássica e moderna da Europa como um longo processo de dominação e silenciamento da loucura, que retoma sua voz a partir das palavras trágicas de Nietzsche e Artaud. Nietzsche apega-se ao anti-hegelianismo de Schopenhauer para alicerçar sua metafísica de artista, ao mesmo tempo em que considera que a filosofia do autor de $O$ mundo como vontade e representação resgata o espírito trágico na modernidade, ao lado da música de Richard Wagner. Em Foucault, o contraponto ao primado da razão dialética na psiquiatria de Pinel e na filosofia de Hegel encontra-se nas experiências criadoras de artistas e pensadores como Artaud, Nietzsche, Goya e Van Gogh, exemplos daquilo que chamou de "ausência de obra". Tanto Nietzsche quanto Foucault partilham, assim, de uma crítica à razão dialética, seja ao tratar do silenciamento da experiência trágica da loucura, seja ao postular a morte da tragédia Ática.

Podemos afirmar também que Foucault entende a loucura sob um ponto de vista ontológico, uma vez que ele se remete à maneira como Nietzsche apresenta as noções de dionisíaco e apolíneo. Para Nietzsche (2007, p. 29), estes são “[...] poderes artísticos que, sem a mediação do artista humano, irrompem da própria natureza, e nos quais os impulsos artísticos desta se satisfazem imediatamente e por via direta". Este é o pressuposto de Nietzsche, em O nascimento da tragédia, para pensar a tragédia Ática. Ao estabelecer a diferença entre o coro dionisíaco e o drama trágico, o filósofo argumenta que, no primeiro, pressupõe-se o personagem Dionísio, embora ele nunca se encontre representado (todos os participantes do coro eram sátiros que se transfiguravam e formavam uma nova visão), enquanto no drama trágico o personagem dionisíaco encontra-se representado, visível ao público.

A partir daí, Dionísio se torna um herói épico que, por muito tempo, foi o único herói existente na tragédia, cuja única finalidade era o sofrimento do deus báquico. O interessante dessa personificação de Dionísio na tragédia é que ela só foi possível por intervenção de Apolo: Dionísio se torna um personagem individual que carrega profundo sofrimento por causa dessa individuação. Sobre isso, Nietzsche (1992, p. 69) alerta: “[...] com a mesma certeza cumpre afirmar que jamais, até Eurípedes, deixou Dionísio de ser o herói trágico, mas que, ao contrário, todas as figuras afamadas do palco grego, Prometeu, Édipo e assim por diante, são tão somente máscaras daquele proto-herói, Dionísio”. Em decorrência disso, apresenta-se uma importante diferenciação entre as tragédias de Ésquilo e Sófocles, de um lado, e as de Eurípedes, de outro: se na tragédia dos primeiros as personagens principais eram sempre máscaras de Dionísio, em Eurípedes, é o homem comum que se encontra no centro do palco, com seus vícios e erros. Por trás dos heróis trágicos esquilianos e soficlianos, "[...] por trás de todas essas máscaras se esconde uma divindade, eis o único fundamento essencial para a tão amiúde admirada 'idealidade’ típica daquelas figuras célebres” (NIETZSCHE, 1992, p. 69). Desta forma, Dionísio aparece, através de A polo, numa pluralidade de configurações, trazendo o conhecimento divino sob as máscaras de Prometeu e Édipo.

Para Nietzsche, é em oposição ao conhecimento universal, obscuro e enigmático da tragédia Ática que encontramos o início de uma nova comédia a partir do drama de Eurípedes, que não traz fundamentos metafísicos ou ontológicos da existência, mas abarca de maneira superficial nas trivialidades cotidianas dos homens. Dá-se, desta forma, uma sobreposição do drama de Eurípedes sobre a tragédia de Ésquilo e Sófocles, num momento de apequenamento da própria noção de homem, uma vez que se encontra, agora, no

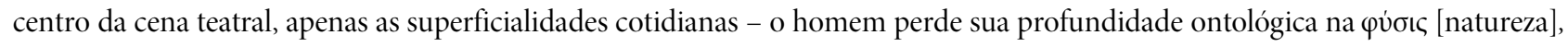
sustentando-se agora unicamente na experiência dialética do $\lambda$ ó $о$ ç $[\log o s]$.

Desta forma, Eurípedes abre para o drama um caminho em direção à comicidade. "Excisar da tragédia aquele elemento dionisíaco originário e onipotente e voltar a construí-la de novo puramente sobre uma arte, uma moral e uma visão de mundo não-dionisíacas - tal é a tendência de Eurípedes que agora se nos revela em luz meridiana” (NIETZSCHE, 1992, p. 78). Ao substituir Dionísio pelas virtudes socráticas, ele tornou-se, por suas peças, o poeta que julga, abrindo assim a poesia para a moralização do homem. A tragédia perde então aquela forma universal da vitória na derrota, e agora impõe-se uma consciência julgadora através da dialética socrática. Partindo desta divisão, o filósofo alemão busca rebater as teorias estéticas de sua época que compreendiam a arte como pura manifestação de uma subjetividade criadora, bem como a compreensão de uma arte cuja finalidade é pedagógica-utilitarista, através de uma ontologia da obra de arte encarnada nas pulsões dionisíacas e apolíneas. Tal ontologia se sustenta, em grande medida, pela hipótese de que há um elemento negativo (dionisíaco) em relação à pura representação luminosa do discurso (apolíneo). E é esta tensão que sustenta, para Nietzsche, aquilo que se pode chamar de uma arte trágica. 
De forma análoga, Foucault parte de uma ontologia da loucura para escapar da armadilha antropológica que sustentou a percepção moderna da loucura enquanto "alienação" e "doença mental" - percepção esta que História da loucura aponta como sustentada pela dialética hegeliana. Tal como o dionisíaco em Nietzsche, Foucault reconhece que o ser da loucura aponta para o vazio da existência, os limites da razão e o embate constante entre o homem e a morte. Foucault resgata a dicotomia nietzschiana através das noções de experiência trágica da loucura e de consciência crítica da loucura, opondo o cósmico trágico ao moral crítico: a experiência trágica traz visões cósmicas do mundo, a morte, os mistérios e o fascínio do que não cabe no logos, enquanto a consciência crítica da loucura carrega uma reflexão moral e lógica sobre os vícios humanos.

Foucault argumenta que ambas conviviam durante o Renascimento. No entanto, com a consolidação da percepção clássica, a consciência crítica acabaria por silenciar a experiência trágica, abrindo espaço para a experiência clássica da loucura nos séculos XVII e XVIII. Enquanto a experiência trágica manifestava-se na iconografia renascentista, marcadamente em Bosch, Bruegel e Dürer, a consciência crítica era percebida em obras filosóficas e literárias, como no Elogio a loucura, de Erasmo, e em A nau dos insensatos, de Brant. Enquanto na consciência crítica a loucura se encontra subordinada à razão, sempre com uma finalidade moralizadora e educativa, a experiência trágica conduz para a ruína do sentido, expressando nos próprios limites da representação a negatividade da morte e do nada. Durante o período renascentista, a loucura aparece ligada às grandes inquietudes causadas pela peste, pela guerra e pela fome, que dominam a existência humana da época; rapidamente, o louco é incorporado nesse imaginário, anunciando o fim dos tempos, o apocalipse, e encarnando as formas demoníacas do caos. Mas se até metade do século XV, nas palavras de Foucault (1972, p. 26), “o tema da morte reina sozinho" e "[...] o que domina a existência humana é este fim e esta ordem à qual ninguém escapa”, o início do século XVI marca a predominância da consciência crítica, cômica e moralizadora. Nesta, a loucura é interiorizada no homem, perdendo seus poderes de revelação.

Ao traçar as oposições entre a experiência trágica e a consciência crítica, Foucault escreve que a experiência trágica se manifesta, principalmente, nas artes plásticas, como em Bosch, Bruegel e Dürer. Embora seja inegável que as imagens destes possuam temas em comum com a escrita de Erasmo e Brant, como a dança dos mortos e a própria nau dos loucos, Foucault (1972, p. 28) observa que "a bela unidade" entre "[...] o verbo e a imagem, entre o que é figurado pela linguagem e o que é dito pela plástica" começa a se desfazer. Assim, para o autor de História da loucura, "[...] por seus valores plásticos próprios, a pintura mergulha em uma experiência que se desvia cada vez mais da linguagem, qualquer que possa ser a identidade superficial do tema”. Tal desvio se explica pelo esoterismo de tais obras, por um desenvolvimento autônomo em torno de sua própria potência de imagem, distanciando-se das temáticas morais e pedagógicas da consciência crítica.

Foucault (1972, p. 28) chama essa distância entre linguagem e imagem de "ruína [délabrement] do simbolismo gótico". Isso indica que as imagens pintadas por Bosch começam a se libertar da iconografia gótica, presa a um simbolismo fechado com significações bem delimitadas, passando então a girar em torno de si mesmas. O resultado disso é que as imagens não revelam mais sua conexão com o mundo social e moral, mas simplesmente sua pureza de imagem insana. Diz Foucault (1972, p. 29): "[...] liberada da sabedoria e da lição que a ordenavam, a imagem começa a gravitar ao redor de sua própria loucura”. Para além do limite das imposições morais que regulavam a vida social cristã, as imagens de Bosch, Bruegel e Dürer avançam em direção ao seu próprio ser, à sua própria pureza plástica enigmática.

Em suma, a oposição estabelecida por Foucault é entre uma experiência trágica em que a loucura aparece em sua espessura ontológica, como fato encarnado no mundo, e uma experiência crítica, na qual a loucura, sob as roupagens de uma grande comédia, é retratada como uma dimensão inerente aos costumes dos homens. Assim, Foucault reproduz a mesma estrutura com que Nietzsche, em o Nascimento da Tragédia, contrapõe a fundamentação ontológica da tragédia grega de Sófocles e Ésquilo às peças humanistas de Eurípedes. Em tons líricos, tanto Foucault quanto Nietzsche farão o elogio desta arte trágica em que os mistérios da morte e do sofrimento se veem transfigurados em imagens que apontam para o limite do logos, da razão. 


\section{O ANACRONISMO DA HIPÓTESE DE FOUCAULT}

O que gostaríamos de questionar aqui é a validade historiográfica desta leitura de Foucault sobre a distância entre as obras escritas e a iconografia medieval. A princípio, uma rápida comparação entre a tese da "ruína do simbolismo gótico" com os principais estudos de história da arte sobre os séculos XV e XVI mostra que a leitura de Foucault não só é equívoca, como jamais foi sequer considerada pelos historiadores da arte. Basta lermos os grandes estudos sobre a iconografia da Baixa Idade Média e do Renascimento - como os de Aby Warburg (2013), Erwin Panofsky (1979), Johan Huizinga (2013) e Giorgio Agamben (2012) - para perceber o quanto havia um forte diálogo entre os significados das obras escritas e das obras plásticas. É, inclusive, parte do método historiográfico desses autores reconstituir as bases discursivas que explicam e fundamentam as construções das imagens que, para nós, aparecem como enigmáticas.

Como exemplo máximo desse tipo de trabalho, basta citar a primorosa obra Saturno e a Melancolia, de Klibansky, Panofsky e Saxl (1979). Os autores mostraram detalhadamente como uma única gravura de Dürer não só retoma dois mil anos de tradição médica, religiosa e filosófica, como também sustenta uma espécie de "síntese" perfeita de como o humanismo renascentista releu textos de magia, medicina e demonologia. A imagem de Melencolia I soa completamente ilegível e enigmática para o homem contemporâneo; no entanto, ela transforma e reelabora sentidos recorrentes da tradição iconográfica anterior ao Renascimento. Não há, nas obras plásticas da época, completa autonomia do símbolo imagético em relação às obras literárias.

O mesmo se aplica às pinturas de Bosch e de Bruegel. Para sustentar nossa interpretação, vamos nos limitar aqui a uma análise rápida de O Jardim das Delícias, famoso quadro em que os seres monstruosos pintados pelo holandês são criados a partir dos discursos moralizantes da doutrina cristã. Algumas das imagens - como a dos pássaros no painel central de O Jardim das Delícias Terrenas são chistes sexuais com palavras da língua holandesa: "Vogelen", o plural de pássaro (Vogel) em holandês, refere-se também ao ato sexual. Daí que, no Jardim das Delícias, o ato sexual pecaminoso é representado simbolicamente a partir da imagem de pássaros que devoram frutos, em meio aos corpos nus que esbanjam luxúria em práticas de prazer gratuito.

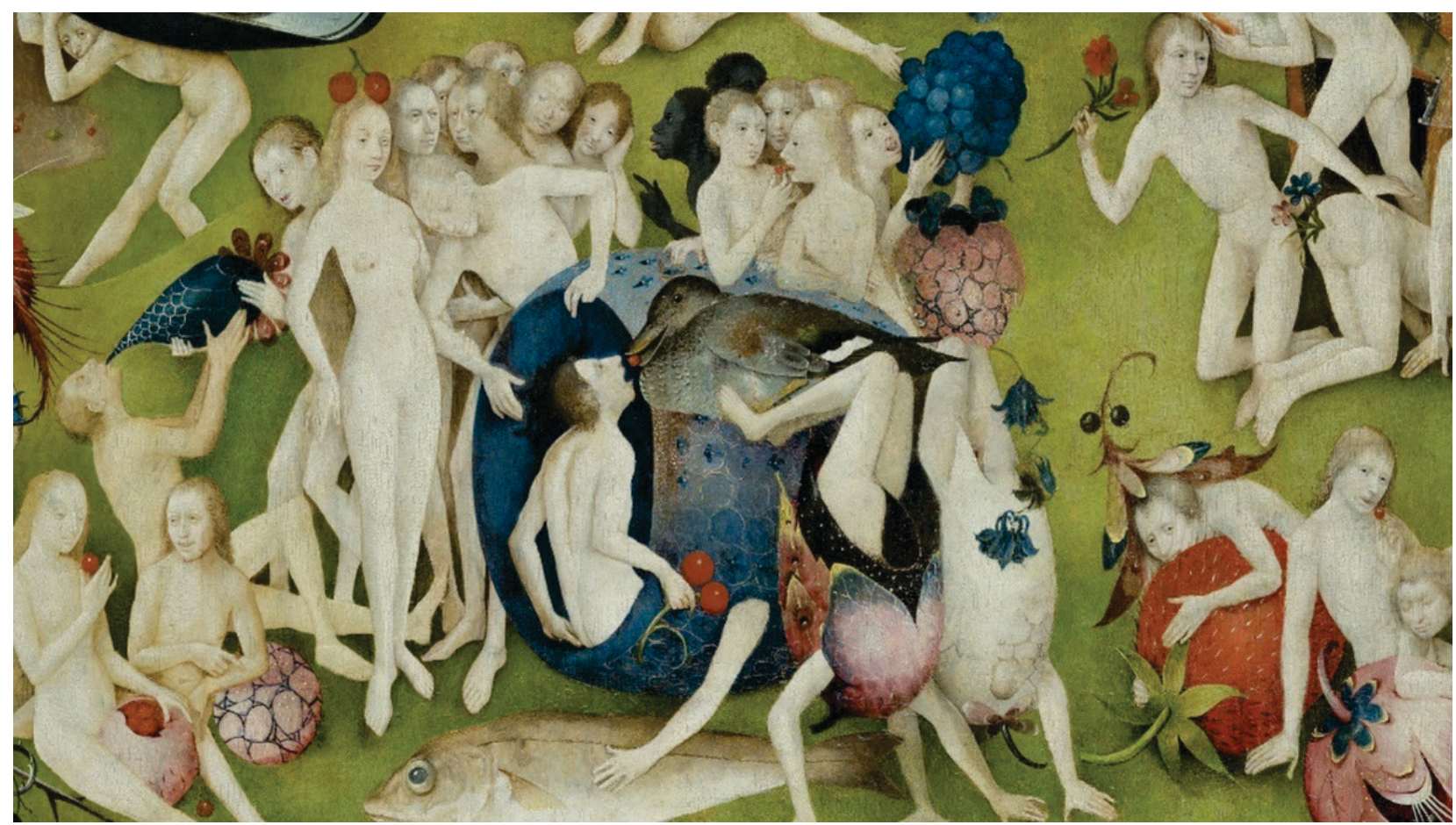

Figura 1: detalhe do painel central de O Jardim das Delícias, de Hieronymus Bosch.

Fonte: https://tuinderlusten-jheronimusbosch.ntr.nl/en

As frutas representam simbolicamente o sexo enquanto fruto proibido, numa evidente inversão chistosa do mito do gênesis: "Frutificai, disse Ele [Deus], e multiplicai-vos, enchei a terra e submetei-a. Dominai sobre os peixes do mar, sobre as aves dos céus e sobre todos os animais que se arrastam sobre a terra" (Gn 1:28). Ora, é justamente uma inversão irônica da ordem de "frutificar" e 
"dominar os animais" que é simbolizada pelas imagens monstruosas de Bosch. O gesto de comer os frutos e dominar os animais que se espalha ao longo do mundo terreno no painel central revela simbolicamente a perversão dos homens imorais, que desrespeitam em sua soberba a lei da economia divina. Deus ordenou que o sexo ficasse restrito à reprodução - o que Bosch simboliza ao colocar um coelho ao lado de Adão e Eva, no painel do paraíso - enquanto os homens buscam unicamente os prazeres da carne, reproduzindo em suas ações cotidianas o gesto pecaminoso originário de comer do fruto proibido. Tais referências a passagens bíblicas, inclusive, são bem evidentes até para o homem do século XXI.

Já na terceira parte do tríptico, na qual Bosch figura as imagens monstruosas do inferno, percebemos também referências diretas à tradição moralizante cristã. As imagens de homens sendo torturados em gigantescos instrumentos musicais simbolizam a condenação da música profana, relacionada no imaginário medieval aos pecados da luxúria; os pequenos pássaros que saem do ânus de um homem sendo engolido por um pássaro são uma construção simbólica dos flagelos implicados aos sodomitas e aos avaros; e a mulher que olha o reflexo de sua própria imagem enquanto é abraçada por um animal sombrio simboliza o pecado da vaidade, ilustrada em todo medievo a partir do mito de Narciso, aquele que mortalmente se apaixonou pela própria imagem ${ }^{3}$. O sapo que, aqui, aparece entre os seios da bela jovem, representa a impureza de uma alma não-casta, não-virgem, ou seja, tomada por pensamentos sexuais impuros e diabólicos. Este sapo - por si só um símbolo bem conhecido do demônio na época de Bosch reaparece em vários pontos do tríptico, para ressaltar que o demônio é ardiloso e se esconde onde menos se espera.

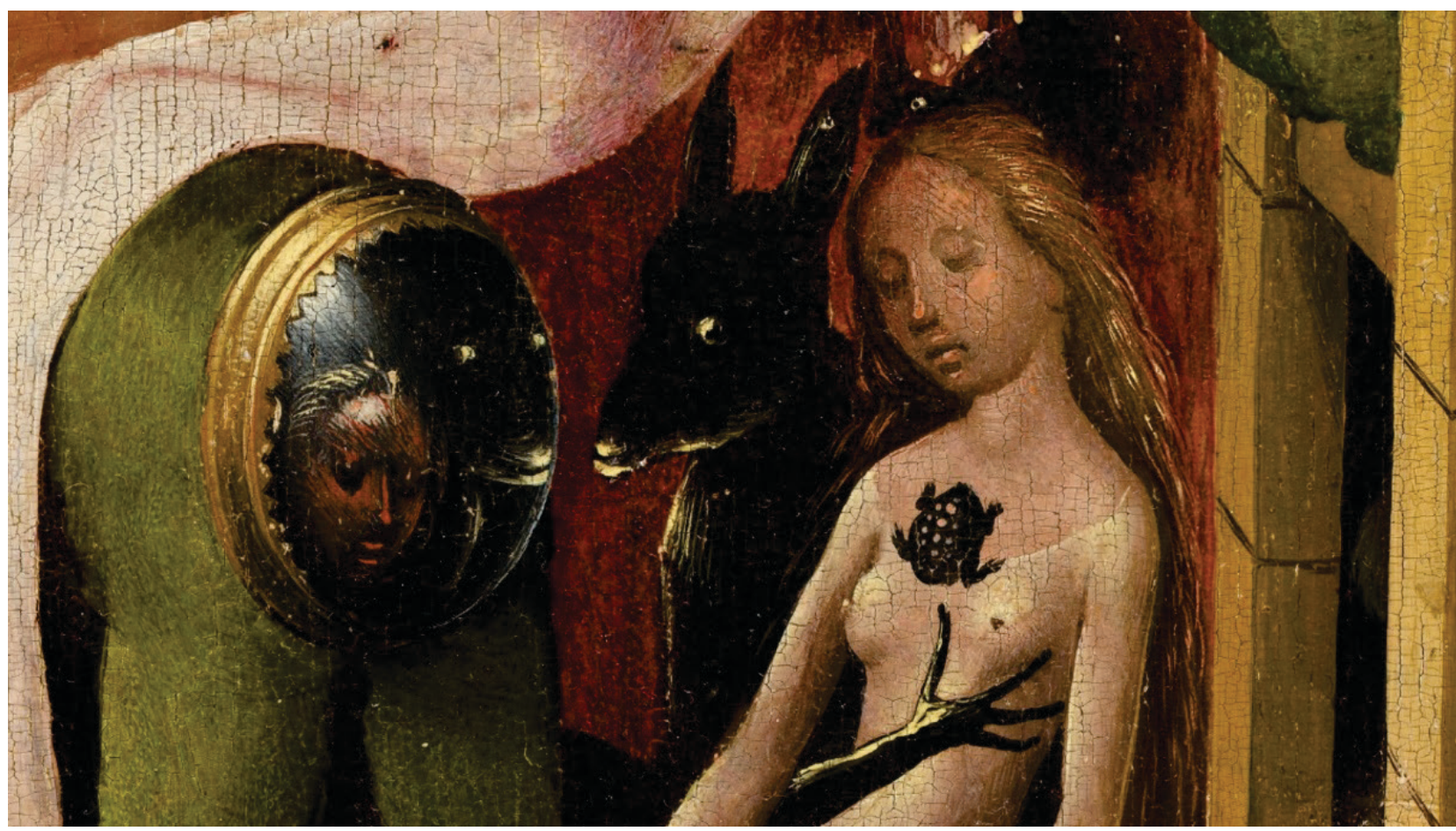

Figura 2: detalhe do painel direito de O Jardim das Delícias, de Hieronymus Bosch.

Fonte: https://tuinderlusten-jheronimusbosch.ntr.nl/en

É inegável, portanto, que a iconografia esboçada por Bosch parece reafirmar o mesmo sentido pedagógico que aparece na Nau dos Insensatos, de Brant, ou na crítica de Erasmo ao homem pecador do medievo. Não há ruína do simbolismo enquanto fato histórico, como insinua Foucault; mais precisamente, é a alegoria de uma linguagem para nós já esquecida que constitui um enigma. Mas este enigma não é próprio a uma ruína da linguagem, e sim a um desnível histórico entre nós e os medievais.

\footnotetext{
${ }^{3}$ A este respeito, conferir as análises de Agamben na terceira parte de Estâncias, "A palavra e o fantasma: a teoria do fantasma na poesia de amor do século XIII", sobre a importância dos "fantasmas" (imagens) na cultura literária medieval. Agamben discute de que modo a categoria médica de "amor louco" ou "amor hereos" consolidou um pensamento fantasmático sobre a linguagem originalmente medieval. Tal doença é considerada uma afecção melancólica na qual, tal como Narciso e Pigmaleão, os cavaleiros e poetas nobres se apaixonavam pela imagem fantasmática de uma mulher, em detrimento de um amor carnal. É justamente na valorização dessa experiência da loucura melancólica como capaz de conduzir o poeta à salvação que se sustenta uma revalorização do amor profano no baixo medievo; tal seria a origem histórica do que chamamos hoje de "amor cortês". Vale ressaltar, no entanto, que o pensamento plantonista cristão associou sempre os "fantasmas" à falsidade das imagens e às artimanhas do demônio: é isso que se expressa, aqui, na iconografia de Bosch.
} 
O que fica evidente, dessa forma, é o quanto a leitura de Foucault é anacrônica: ela aplica os valores da noção de autonomia própria às teorias estéticas do século XIX sobre obras de arte que nada contêm de autônomas ou mesmo de enigmáticas em relação ao seu próprio contexto. Toda a iconografia medieval e cristã é completamente sustentada por textos literários e de linguagem - fato que só será abalado, no Ocidente, a partir da experiência romântica da arte original, no século XIX. E é justamente sobre essa teoria da originalidade e da autonomia da obra de arte romântica que Nietzsche sustenta sua ontologia da obra de arte em O Nascimento da Tragédia. Há confusão, portanto, entre o âmbito da ontologia e da historiografia na interpretação foucaultiana: a autonomia dos símbolos em relação ao contexto literário só é concebível historicamente a partir do século XIX; o que Foucault faz é aplicar um conceito de arte romântico a uma obra plástica que pertence a outro contexto, intuindo assim de modo equivocado uma "ruína do simbolismo" como fato histórico per se.

\section{IMAGENS PARA ALÉM DAS PALAVRAS?}

Mas como, então, Foucault chegou a esta hipótese de uma "ruína do simbolismo gótico", opondo o que ele chama de "obras de linguagem" a essas obras plásticas que, em suas próprias palavras, "se afastam da linguagem"? Ao nosso ver, isso se explica pela forma como O Nascimento da Tragédia induziu Foucault a opor o logos da tradição filosófica dialética ao conceito de arte da metafísica nietzschiana.

Toda a questão aqui é perceber como o que Foucault considera um "afastamento da linguagem" é entendido, na verdade, como uma tensão estética entre o logos e seus próprios limites. Ou seja: Foucault parece confundir a noção mais geral de "linguagem” (pensada enquanto código ou sistema estruturante) com a noção mais específica de logos (discurso, palavra, razão) da tradição dialética. Ora, as obras de Bosch e de Dürer são completamente sustentadas pelos códigos da linguagem pictórica da época e podem muito bem ser consideradas como uma espécie de tradução intersemiótica dos textos literários que Foucault agrupa como exemplos da experiência crítica da loucura. A argumentação de Foucault se sustenta, portanto, numa certa compreensão de que as obras de arte plásticas não possuem, em si mesmas, um certo código, uma certa ordem estruturante e racional dos elementos pictórios.

Tal "autonomia" que ele confere às imagens insanas de Bosch é, na verdade, um eco da teoria goethiana do símbolo, incorporada por Nietzsche em O Nascimento da Tragédia. Para Goethe, a perfeição natural do símbolo se opunha à arbitrariedade da alegoria, de modo que o símbolo expressa o seu conteúdo sem a necessidade de se amparar em outro texto. Isto é: um símbolo perfeito significa a si mesmo; ele é "autônomo", na medida em que "dá a própria lei”. Estaria, dessa forma, mais próximo da "natureza” do que da "cultura": qualquer ser humano poderia entender seu sentido "imediatamente" - ou seja, sem a mediação de uma linguagem arbitrária. No vocabulário platônico de Goethe (2003, p. 116): "O procedimento simbólico converte o fenômeno em ideia, a ideia em uma imagem, e de tal modo que a ideia, na imagem, permanece sempre infinitamente ativa e inatingível, e mesmo pronunciada em todas as línguas, permanece contudo inexprimível".

Sabemos hoje, depois da virada estruturalista, que tal funcionamento do signo é impossível. Toda linguagem depende, em maior ou menor medida, de um sistema de referências arbitrário e de uma diferença mínima - a barra entre o significante e o significado no esquema s/S - que estrutura a possibilidade de simbolização ${ }^{4}$. A ideia de que os signos visuais são imediatamente uníssonos com seu próprio significado, de que independem de uma "linguagem" arbitrária exterior, é um preconceito milenar do Ocidente, que desde a Grécia clássica toma a "visão" enquanto sentido privilegiado para apreensão da "verdade”. De forma que não há diferença entre as obras de arte plásticas em relação às obras literárias no que diz respeito à arbitrariedade dos signos. O engodo de Foucault se sustenta justamente aí: considera que haja uma diferença essencial entre a linguagem visual e a linguagem literária, colocando a primeira como originária e independente da historicidade do logos, e a segunda como exposição lógica de um sentido historicamente específico.

${ }^{4}$ A este respeito, conferir a argumentação de Agamben (2012) sobre o simbólico na última parte de Estâncias, "A imagem perversa: a semiologia do ponto de vista da Esfinge". 
Daí que toda vez que Foucault vá apresentar sua noção de "ausência de obra", opondo-a à razão clássica e moderna, ele cite como exemplo as obras de artistas que se encaixam perfeitamente na ontologia da obra de arte de Nietzsche. Tal ontologia entende que as obras de arte legítimas são compostas pela tensão entre dois instintos humanos: um instinto de ordem e representação visual, simbolizado pelo deus da luz Apolo, e outro de caos chistoso e irônico, simbolizado pelo deus da embriaguez, Dionísio. Essa tensão, baseada na oposição entre a representação racional e a vontade irracional de Schopenhauer, por sua vez, se desdobra nos pares visívelinvisível, luz-escuro, imagem-música, razão-loucura, etc. Dessa forma, quando Foucault diz que a loucura é “ausência de obra”, está considerando que a loucura, enquanto pura negatividade, expressa exatamente os limites do logos - entenda-se aqui, os limites da linguagem articulada. A loucura é, assim, aquilo que sobra da linguagem quando é esvaziada do logos: "experiência primitiva", "ruído", "balbucio", "silêncio" são os termos utilizados por Foucault para caracterizá-la.

É com base nesses vocábulos que Roberto Machado (2005, p. 27) vai dizer que não há uma ontologia da loucura em Foucault, posto que a loucura aí só apareceria encarnada em obras de arte, como evidência de uma experiência da linguagem. Mas uma leitura mais atenta de História da Loucura e, mais precisamente, do prefácio suprimido de 1961, mostra o contrário: a loucura não é, como pensa Machado, a linguagem da ausência, mas, antes, a ausência da linguagem. A crítica à razão dialética, que atravessa todo o livro, supõe a existência atemporal de uma certa "falha", de um certo "esgotamento", de um certo "limite" do logos, que se apresentaria toda vez que as experiências estéticas revelam-nos a própria crise da representação. Não há defesa de uma "linguagem da loucura" na tese de doutorado de 1961, porque ali a loucura não tem um código, um sistema de referências próprio.

É precisamente isso que Foucault exemplifica com a ideia de uma "ruína do simbolismo". O sentido "enigmático" das obras de Bosch nada mais seria que a expressão da distância absoluta, da incomensurabilidade, da incompatibilidade, da falta de causalidade natural entre logos e pensamento ${ }^{5}$. Que haja um pensamento aquém e além da linguagem, aquém e além do discurso, aquém e além da própria história, ou seja, um pensamento sem representação, um pensamento sem mediação: é isto que Foucault insinua com a noção de "ausência de obra". Bosch o teria feito, segundo Foucault, com as imagens autônomas que significam a si mesmas em vez de simplesmente representar a pedagogia cristã. Mas é evidente que uma leitura historiográfica precisa de Bosch não sustenta tal visão, uma vez que toda a iconografia medieval é fortemente marcada por um simbolismo pedagógico e moralizante.

\section{CONCLUSÃO}

A anacronia da interpretação foucaultiana não expressa meramente uma imprecisão historiográfica, mas sim uma precisão teórica em relação a Nietzsche, herdeiro da teoria goethiana do símbolo. A autonomia das imagens de Bosch em relação ao seu próprio contexto histórico confirmaria, assim, a própria ideia nietzschiana de um saber dionisíaco atemporal, esotérico, imediato, mais originário que os códigos da linguagem e da cronologia da história. Tal como Nietzsche questiona a dialética de Sócrates elogiando a tragédia Ática, Foucault vai criticar a dialética de Hegel em favor de uma experiência trágica da loucura. Porque, afinal, na dialética hegeliana - aquela que, segundo Foucault, sustenta arqueologicamente o conceito de "alienação mental" dos psiquiatras - não há distinção entre a história do homem e a história do logos. A arqueologia, tal como aparece no prefácio de 1961, era considerada precisamente como o método historiográfico que radicalizava essa dissociação. Nas palavras de Foucault (1994, p. 160, grifos nossos): "Nunca quis fazer a história dessa linguagem; antes, a arqueologia desse silêncio".

\section{REFERÊNCIAS}

AGAMBEN, G. Estâncias: a palavra e o fantasma na cultura ocidental. Trad. Selvino José Assmann. Belo Horizonte: Editora UFMG, 2012.

\footnotetext{
${ }^{5}$ Sabemos o quanto pesam sobre essas considerações as teses de Nietzsche $(2003,2008)$ a respeito das origens metafóricas da linguagem e de sua não-naturalidade em relação ao humano, especialmente em Sobre a verdade e a mentira no sentido extramoral e na Segunda consideração intempestiva.
} 
FOUCAULT, M. Histoire de la folie à l'âge classique. Paris: Gallimard, 1972.

FOUCAUlT, M. Préface (Folie et déraison). In : FOUCAULT, Michel. Dits et écrits I. Paris: Gallimard, 1994. p. 159 -167.

GOETHE, J. W. Máximas e reflexões. Trad. Marco Antônio Casanova. Rio de Janeiro: Forense Universitária, 2003.

HUIZINGA, J. O outono da Idade Média. Trad. Francis Petra Janssen. São Paulo: Cosac Naify, 2013.

KLIBANSKY, R.; PANOFSKY, E.; SAXL, F. Saturn and Melancholy: Studies in the History of Natural Philosophy, Religion and Art. Nendeln/Liechtenstein: Kraus Reprint, 1979.

MACHADO, R. Foucault, a filosofia e a literatura. Rio de Janeiro: Jorge Zahar, 2005.

NIETZSCHE, F. W. O nascimento da tragédia: ou helenismo e pessimismo. Trad. Paulo César de Souza. São Paulo: Companhia das Letras, 2007.

NIETZSCHE, F. W. Segunda consideração intempestiva. Trad. Marco Antônio Casanova. Rio de Janeiro: Relume Dumará, 2003.

NIETZSCHE, F. W. Sobre verdade e mentira no sentido extramoral. Trad. Fernando de Moraes Barros. São Paulo: Hedra, 2008.

WARBURG, A. A renovação da antiguidade pagãa: contribuições científico-culturais para a história do Renascimento europeu. Trad. Markus Hediger. Rio de Janeiro: Contraponto, 2013.

\section{(ㄷ) (1) $\circledast$}

Recebido em 07/12/2018. Aceito em 03/02/2019. 